\title{
ISLAM AND RELIGIOUS EXPERIENCE IN THE POSTMODERN
}

\author{
Ahmad Sidqi \\ Doctoral Student in Philosophy \\ Institute of Social Science Uludag University, Turkey \\ Email: asidqi87@gmail.com
}

\section{Abstrak}

Pengalaman ber-Islam di dunia modern membentuk ulang hubungan antara manusia dan Tuhan atas dasar otoritas fundamental dari Al Qur'an. Masjid sebagai simbol, adalah momumen kekuasaan politik yang mengandung sejumlah kontradiksi yang paling mendasar yang mencirikan masyarakat Muslim di dunia modern. Kontradiksi demikian berlaku bagi sejumlah karakter yang diasosiasikan dengan masjid, ia mungkin mencitrakan ciri "terbuka", "toleran", "cosmopolitan", "modern" dari Muslim yang reformis, yang mengepung pemerintah dalam pertentangannya melawan kelompok-kelompok oposisi militant yang mengadopsi Islam sebagai sebuah instrumen naratif dan perjuangan yang berjangkauan luas. Para reformis, aktivis, dan militan Muslim selalu mengatakan bahwa mereka adalah sebuah "gerakan", sebuah "keberadaan" yang masih dalam proses perkembangan dan evolusi. Politik emansipasi memberi perhatian pada, lebih dari segalanya, tema-tema keadilan, kesetaraan dan partisipasi, tema-tema yang pada kenyataannya sama persis pada mana sebagian besar Muslims reformis memberi perhatian. Pengalaman ber-Islam melibatkan pendefinisian ulang identitas yang telah menjadi terseragamkan oleh proses modernisasi global. Pengalaman keber-Islam-an karenanya adalah sebuah panggilan untuk politik emansipatoris yang berarti pencapaian keadilan yang sedang tidak terjadi, distribusi kesejahteraan yang lebih egaliter dan pengambilan keputusan yang lebih demokratis.

Kata Kunci: Islam, pengalaman beragama, postmodernisme

\section{Abstract}

The Islamic experience in the modern world reconstitutes the relation between human and God on the basis of the fundamental authority of the holy Quran. Mosque as a symbol, this monument to political power contains some of the most basic contradictions thats characterize Muslim societies in 
the modern world. A similar distinction applies to the to the morning officialy attributed to the mosque, it maybe "open", "toleran", "cosmopolitan", and "modern" Muslim reformers, embattled governments against increasingly militant oppositional groups which have adopted Islam as an overarching instrument of discourse and struggle. Muslim reformers, activists, and militants nearly always say that theirs is a "movement", a "current" which is still in the process of gestation and evolution. Emancipatory politics is concerned, above all, with themes of justice, equality, and participation, the very same themes that most Muslim reformers are in fact concerned with. Islamic experience involves a redefination of identity in a world which has become homogenized by the globalizing process of modernism The Islamic experience is therefore a call for an emancipatory politics which means justice where there is none, a more egalitarian distribution of wealth and a more democratic system of decision making.

Keywords: Islam, religious experience, postmodernism

\section{INTRODUCTION}

The Islamic Experience in the modern world reconstitutes the relation between human and God on the basis of the fundamental authority of the holy Quran. This is a fundamentally proccess of redefinition which involves a religious reformulation with farreaching political implication. Unlike other monotheistic religions, Islam, at its core, makes no distinctions between individual and individual and between individual and the states. The original position in Islam consisted of the creation in Medina (the holy city of the Prophet) of a just order predicated on the word of God. We cannot therefore examine Islamic religious experience without disscussing it in the political and social context.

At the same time, Islamic religious experience is a response to prevailing interpretations of the world. In the original position, Islam was in part of response to the polytheism of the tribes in Arabian Peninsula and in part to Christianity and Judaism as they were practiced in the Near East. In the modern age, it is a response to modernism and its various manifestation in the West. From the 
beginning of the nineteenth century, Islam has in fact been especially preoccupied with fashioning a response to hegemonic power of the modernizing West and the intrusion into Muslim societies of Western and therefore alien modes of thinking and behavior.

This article will examine the Islamic experience in a attempt to confront modernism both as a weltanschauung and as a set institutions represented by the apparatus of the modern state. The key argument here is that the modern Islamic revivalist movement in all of its parts in various Arab and Muslim countries constitutes primarily a process of evolution. For this reason, it is unlikely that we will find in the corpus of writings by Muslim activist in the current period a coherent and systematic critique that serious enough to generate theories in the future or weather it is simply all an ephemeral reaction to powerful influences from the outside.

Throughout the Muslim world there are sectarian differences, for instance, in the case of Sunnis and Shi'a. But the most important difference is between official Islam and the Islam of the new reformers. The former benefits from government approval - there are religious appointments and there is official government assistance. The news media propagate a version of official Islam. Friday sermons by religious authorities often endorse the ruling authorities and sing their praises. There is a more popular kind of Islam practiced by the masses of people who respond more enthusiastically to sermons of charismatic religious authorities who advocate an oppositional kind of Islam. The following story ilustrates the difference between the two and underscores the contradictions between them.

A picture of a new mosque, a long with a story, appears in the New York Time; "A New beacon of Islam", reads the official description of the gargatuan new seafront mosque in Casablanca, Morocco, which dwarfed a solitary visitor who leaned against an enormous pillar. The minaret, the higest in the world, rises more than 650 feet. At the top is a green laser beam which points the way to Mecca. The mosque sits on a promontory that juts into the Atlantic 
Ocean and contains fifty four acres of traditional Morrocoan marbles and mosaics as well as an eleven hundred ton roof that slides open to reveal the sky.

The mosque was designed by a French arcitect Michael Pinseau in close collaboration with the Morrocan monarch King Hassan II and took five years to complete. Work is still underway on the library, a vast underground garage, and an elaborate project designed to shift the flow of the city's sewage several miles down the coast in order to make sure that the waters washing against the mosque are pure. A national fund raising drive has been mounted. Every morning the French language daily newspaper Le Matin carries the following headline on its front page: "Citizens, respond to appeal of King Hasan II, the commander of Faithful, the unifier, the savior, the assembler, and if you have not already done so, subscribe for the maintenance, upkeep, and management of the Hassan II Mosque."

The Morrocoan government spokesperson say that the mosque is intended to present "an image of a Muslim country that is open, that is tolerant, that is cosmopolitan and that is modern". To underscore his modernizing intent, the King invited the Morrocan women poet Amina Mrili to recite her verses at the inauguration ceremony, to the consternation of the predominantly conservative Muslim society. By the most accounts, it appears that the inauguration ceremony, planned as an elaborate event, was in fact colossal failure. Critics see the mosque as the work of a "supreme megalomatic".

\section{DISCUSSION}

\section{The Symbol of Islamic Society}

As a symbol, this monument to political power contains some of the most basic contradictions thats characterize Muslim societies in the modern world. The Hassan II mosque rises againts the sky in the midst of a decaying and dilapidated urban sprawl in a way that detaches it from and sets it at odds with its immediate surroundings. 
By contrast, the great mosques in Cairo, Jerussalem, and Damascus emerge, almost logically, from the immediate social and architectural landscape. It is a natural thing for an individual, passing by, to want to go into one of these mosques for a brief moment of shelter and respite (Joseph, 1981: 286). It is difficult to imagine anyone doing the same here.

A similar distinction applies to the to the morning officialy attributed to the mosque. It maybe "open", "toleran", "cosmopolitan", and "modern", but only in a specific and very limited way and in a particular direction. It is not open and tolerant as farm as its citizen are concerned - in Morroco as elsewhere in the Arab world, Muslim opposition groups are dealt with very harshly by the state in total disregard of basic human rights and civil liberties. Openness and tolerance are directed toward the West, which the monarch, like other "modernizing" leaders in the Arab and Muslim worlds, tries to emulate. It is no accident that one of the first heads of state to be given a tour of the mosque was none other than Israeli Prime Minister Rabin, who still represents for most of Marroco's urban Muslim poor a country that is an enemy of Islam and of the Arabs.

King Hassan's version of Islam, similar to many others propagated by rulers in the Muslim world, is an "official" one, dictated more by the needs of political power than by the needs of community of believers. This distinction is very important because it accentuates the difference between a discourse that embrance power and one that challanges it. In the great mosques throughout the Muslim worlds, and in the small neightborhood mosques, very few people pay much attention to the Friday sermons of preachers appointmented of a few charismatics preachers who represent the dissident Muslim groups. Millions of cassettes of such sermons quickly circulate throughtout the Muslim world and beyond.

In the time, the king Hassan mosque may eventually become appropriated by common Muslims who may find in it shelter and peace. In Cairo, around the middle of the ninetheeth century, 
Khedive Tawfiq's mother built the Rifai Mosque as a memorial to her power and celebrity. A very poor man in the area, known as Ahmad Abu Shibak, who had a saintly reputation, used to come to the mosque for prayer, meditation, and rest. In a few year, the mosque became known for the corner he occupied in it and people would go there to pray in order to be near him. In spite of the fact that five rulers of Egypt, in additional to the late Shah of Iran, are buried in the mosque, no one comes to visit their graves. In contrast, there are always candle lit where Ahmad is buried; most people come to pay their respects to him. In fact, the mosque has become known as the Rifai mosque after the name of the Sufi order to which Ahmad belonged.

\section{The Clash of Ideologies}

Throughout the Muslim world, a fierce contest is underway over the definition of society, the role of individual, and the nature of the state. The contest pits secularists against Muslim reformers, embattled governments against increasingly militant oppositional groups which have adopted Islam as an overarching instrument of discourse and struggle.

The secularist claim that Muslim oppositional groups are attempting to seize power in order to establish theocratic tyrannies similar to the ones in place in Iran and in the Sudan. Their fear of such an eventuality has at times forced them to lend their support to governments which they have other wish criticized as oppressive and unjust. Secularist accuse Muslim reformers of failing to provide a clear and convincing alternative to the present oppressive system in power (Said, 1993). The reformers respond that only a return to the origins of the faith will halt the process of decay and disintegration now underway in the Muslim World. They argue that other methods such nationalism, socialism, and capitalism have so far been unsuccessful. The maintain that a rejuvenated Islam will enable Muslim countries to gain the necessary power to become respected part of world community. 
There is an immediacy and an urgency to the debate now underway in the Arab world which differs in a marked way from similar debated in the West between secularists and politicized religious group. The difference derives, in part, from the weakness of the Arab regimes, their lack of legitimacy in the eyes of majority of their publics, and the closeness of their alliance with and dependence upon the West. While it is far fetched to think of religious fundamentalist seizing political power in the United States or in Europe, it is very possible that within a few years many of the key Arab governments could become Islamic republics.

Several Western "frames" of this debate have been suggested. The most common and perhaps most persistent is a media frame that places the issue under the rubric of "fundamentalism" qua terrorism and fanaticism. This negative frame relies mostly on stereotypical images of warring Muslims who engage in Holy Jihad (struggle) against the West. Occasionally, this negative frame buttressed by academic interventions (Bernard Lewis, 1990, among others) that argue that a state of war exists between Islam and the West of, as in the case of Samuel Huntington (Huntington, 1993), that the contest is in reality a clash between two great civilizations.

A variant of this frame views religious fundamentalism as a kind of postmodernism in the Third World Which encourages " a selective attention to the past and an eclectic reconstruction of the present" and arrives at an incoherent combination of the modern and the irrational. Pauline Rosenau (1992:152-155) quotes the following awkward, exaggerated, and erroneous caricature in Salman Rushdi's Satanic Verses to illustrate this point:

"History the intoxicant, the creation and possession of the Devil, of the great Shaitan, the greatest of lies progress, science, rights .. History is deviation from the Path, knowledge is a delusion, because the surn of knowledge was complete on the day Allah finished his 
revelation to Mahound .. Death to the timelessness of God. Burn the books and trust the Book".

It would be difficult to find anyone among so-called Muslim fundamentalist speaking in this manner. Muslims do not consider knowledge and admonish Muslims to seek it wherever it may be.

A more responsible frame has been produced by the American Academy Project which offers a more inclusive and less pejorative definition of fundamentalism. Marty and Applenby (1991) argue that "fundamentalists begin as a traditionalist who perceive some challenge or threat to their core identity, both social and personal" and fight back with innovative power. They strive toward a "worldview which they have inherited or adopted and which they constantly reinforce" (pp. ix-x). Such movements reach back to "real of presumed pasts, to actual or imagined ideal original conditions and concepts" and select what they regard as fundamental. They fight against "generalized or specific enemies.. from without or within the group" and under the banner of God.

\section{The Muslim Reformist Voice}

Muslim reformers, activists, and militants nearly always say that theirs is a "movement", a "current" which is still in the process of gestation and evolution. They do not view themselves as having produced a coherent ideology with a blueprint and set of comprehensive and concrete programs of action that govern social, economic, and political matters. Mannheim (1952) argues that a new biological generation, undergoing the rapid of social change, may created new collective impulses and formative principle original to it self. When this happens, says Mannheim, one will see the realization of potentialities inherent in the location and development of a new generational style or a new generation entelechy, In essence, what the new generation of Muslim reformers is trying to do is this: to draw from the past certain lessons or images that help them reinterpret the present and move toward the future. This is at one 
and the same time a restorationist view of history. It is definietely not the classic restorationist view that harks back to a golden era or a mythic ideal past and tries to reestablish this in its full glory.

What us that modern Muslim activists wish to restore? In the first place, Muslim wish to restore the sovereignty of God in human affairs as opposed to the sovereignty of the "people" or the "state" or the "individual". Central to this objective is the belief in Tawhid, which in mystical term means unity with God and in orthodox terms, proclaiming the unity of God. In the second place Muslims wish to restore the centrality of the Quran as the Word of God. Here is the charisma of the text stands opposed to the dictates of reason and tradision: A person is not a Muslim who does not depend on the Quran and the Holy Prophet's Sunnah (saying and deeds), but carries out the dictates of his own mind or follows the practice descending from his fore-fathers, or who conforms to what is happening in the world without carring to ascertain from Quran and the Sunnah as to how to handle his affairs" (Maududi, 1980:21) In the third place, Muslim activitist wish to restore patterns if behavior that are predicted on basic Islamic principles, duites, and obligations: as vice regent of God on earth, man is under obligation to learn of his household, and members of society. To service all of the faith. One cannot find this knowledge is one's self (Nafs) which only contains corporal urges and may lead a person to drink wine, commit adultery, and be unjust to others. Neither should one rely on the advice of others who may be oppresive and use other people for selfish purposes.

The duties of every Muslim are enshrined in a set of obligations that govern every aspect of a person's life and are predicted on the following pillars: daily prayer (Salah) which is perfomed five times a day following cleaning of the body (Wuduablution); fasting during the month of Ramadan; Zakat, which literally means purity and cleanliness and consists of setting aside aportion of one's wealth to be given to the needy and the poor 
(considered a way to purify one's Nafs); and finally, Hajj or pilgirimage to Mecca at least once in one's lifetime.

The rituals are supposed to prepare the individual for a larger and more important task, namely Jihad. Here is how Maududi describe it: "It would be enough to state that the real objective of Islam is to remove the lordship of man over man and to establish the kingdom of God on Earth. To shake one's life and everything else to achieve this purpose is called Jihad while Salah, Fasting, Hajj and Zakat are all meant as preparatory for this task" (Maududi, 1980:243). For most Muslim scholars, bad government- which means unjust government- is the roof of all evil in the world. Here it must be noted that there are governments which do not rest upon the sovereight of God but which are stilljust, and others which are Muslim and unjust. The critical difference lies in adherence to God' edicts in order to ensure justice for all. A just government is a strong one, one which will prevail over a Muslim government which is unjust. Jihad therefore becomes synonymous with the struggle for justice.

In Islam, there are four major schools of thought -Hanafite, Malikite, Shafiite, and Hambalite - and a number of variations in the interpretation of basic text. One approach, Ijtihad, which literally means individual interpretaions on the basic tenets of the faith, is encouraged by the prophet himself. He showed his followers the necessity of Ijtihad. In one story, he ordered some of his followers to hurry to a specific town in order to carry out a particular task and order of their leader, waited until they reached their destination. Upon their return, they asked the prophet for this opinion. He aggred with boths sides, thereby endorsing private initiative even in such important matters (Gannoushi, 1982: 34-35).

In a attempt to respond to rapid social change in their societies, Muslim reformers have tried to reaffirm the charismatic structure of the Quran and the Sunnah. Despite several decades of secularizing tendencies, governments in Muslim societies have failed to partition the social and cultural space in a way that leaves a 
limited area for the religious sphere. The various governments tried to use the powerful instruments of modernization and its institutions as a way to counter the influence of religious rivals. They tried to coopt Islamic symbols, as a way of gaining legitimacy for themselves in the eyes of their publics. When this strategy failed, they restored to outright repression (as is the case in Egypt, Algeria, and elsewhere).

Central to the debate between secularist and Muslims in the question of how to confront modernity and how to organize the political, social, cultural, and economic space in modern Muslim societies. They key argument here is that Muslim reform activities amount to a fundamental critique of modernity and its institutions. This critique is in the process of formation and has not yet yielded major result at the levels of normative theory theory. It is therefore too early to make a sweeping assessment of this current. All that can be done at the moment is to take stock of what has been done so far by sketching out a basic outline of its main themes in order to see the direction in which developments appear to be heading.

Rashed Gannoushi, the leader of religious revivalism in Tunisia abd one of the leading theorist of the contemporary Islamic revival, argues that we are now whitnessing the end of the era of modernism in the West. He refers to it as the era of "rebellion against God" (Gannoushi,1982: 173) which brought about the "disasters of colonialism and wars, widespread famine, sexual diseases, serious economic and phsycological problems, and rampant consumerism that destroyed the environment". For Gannoushi, modernism originated in Europe following a series of revolutions that began with the French (1789/ and ended with the Bolshevik (1917). Modernism strangled the natural and instinctual dispositions of the individual toward God, religion, the family and public morality and glorified reason, science and progress.

In opposition to this era of Jahiliya (ignorance and darkness), Gannoushi suggests a new era predicated on the recognition of human instinct, the unity of the spiritual and temporal, and the centrality of man's existence as God's vice regent on earth. Man, for 
him, is a religious being. He has no natural right that he derives from himself or from others. Instead, there are rights and obligations which derive from the grace that God bestows upon the person.

Gannoushi's journey of discovery, or what he calls his journey of migration back to the self, provides an important setting for his critique of modernism and its manifestations in the Arab world. "I saw the light,"he says, "in an oasis on the edge of the Sahara in the southern part of Tunisia, whose people were known as rebels and warlike" (Ganousshi, 1992: 174). He was born in 1941, a period during which his hometown was caught in the middle of the Second World War that was raging between "competing Western forces. "Years later, he says, this peaceful oasis became an arena of conflict between the French colonial army and the first Tunisian armed rebellion. The Franch army was able, after a number of atrocities and local acts of treason, to capture the soldier who had led the uprising and to execute him in the village square. The martyrdom of this soldier eventually led to another uprising in the 1950s carried out by religious figure who became the founder of armed Islamic resistance (Jihad) againts French colonialism. Here Gannoushi relates a scene that he "could never forget (as if carved in stone in my soul)" where the French soldiers dumped the bodies of dead Mujahidin (fighters) in the village square and force the men, women, children to walk by to look at them. The rebellion spread throughout spread throughout the countryside to point where the nationalist (secular) leadership represented by Bourguiba began to worry about the rising influence. Eventually, the secular nationalists won the battle and achieved independence by making their own deal with the French. The betrayal of the forces of Islamic resistance by the secular nationalis forces thus became a central point of conflict between the two groups not only in Tunisia but throughout the various countries in North Africa and elsewhere in the Arab world. Decolonization therefore meant the ascendancy of the seculars with the help of the former colonial masters and the temporary suppression of Islamic groups that formed the core of popular resistance to colonialism. 


\section{The Muslim Struggle}

The theme of betrayal is commonly held among Muslim reformers and oppositional groups. Several historical instances illustrate its persistence throughout the Arab world. A recent example of this phenomenon is the ascendancy of the Palestine Liberation Organization as a result of the signing of the peace accords in Washingon D.C on September 13, 1993. Yasser Arafat's Fatah group has consolidated its possition with the help of the Israel Government. Both the PLO and Israel have reached the conclution that they confront the same enemy, namely, Islamic fundamentalism in the occupied teoritories. Muslim Palestinian dissidents are hunted down by the Israeli authorities with the assistance of the PLO.

Gannoshi's journey take him to the Levent (Syiria and Egypt) where he joins the ranks of Nasser's Arab socialist Union. He is severely disappointed as he discovers that the Arabism (nationalism) in vogue (represented by Nasserism in Egypt and the Ba'th Party in Syiria) at the time is simply not "authentic" enough and fails to represent the deepest aspirations of the majority of the people.

Gannoushi departs for France in 1968 in order to purse higher educaqtion in Paris. Here he experience "the difficulties of life, its mad pace, it individualism, materialism and hypocrisy" (Gannoushi, 1992:178). He finds "in this well some peace and shelter from the tempests that pursued me in a small oasis, a tiny mosque in a humble house in a poor working class neighborhood which some North African students helped establish". It becomes the nucleus of Islamic Da'wah (missionary activity). He learns "humility, service to others, religious witness, and austere living". He and his friends spread out among the Muslim student community and the poor workers teaching, arguing, and spreading the message of Islam: "We went to them in their poor quarters and their rotten bars and, in Latin Quarter, we argued with students from all over the Muslim world, especially from North Africa". He establishes friendships that become, useful in later years. His stay in Paris is described as the" most difficult part of my life". 
Upon completion of his studies, he returns to Tunisia through Spain "the lost paradise of Andalus" (in reference to the golden era of Islamic rule in Spain): "I passed through Cordoba and wept in its beatiful mosque". He returns to his oasis to "renew my struggle against Westernization which, by then, had become embodied in several generations of my people, in a state and institutions, in order to rediscover the Arabism of the oasis, of Islam and its message" (Gannoushi, 1992:178-179).

Gannoushi's migration (hijra) may be described as a journey of discovery, a Conradian "journey within" in search of authenticity and of one's place in the universe, one's roots and identity. In the contemporary Arab world, as in deed throughtout the Third World, there have been maqny such journeys involving troublesome and transforming encounters with modernism. A 1938 novel by Egyptian author Tawfic Al-Hakim, A Bird From the East, describes the sentimental journey of a young Egyptian student who goes to Paris to study literature, carrying with him Tales of Platonic love and ideal romance. He falls in love with beatiful Parisian Girl, becomes the prisoner of a new set of strange values and costums, is betrayed and returns to Egypt where he learns to look more realistically at the drabness and sordidness around him.

Another Egyptian novelist, Yahya Hakki, describes the jourey of another Egyptian student in London in his book The Lamp of Umm Hashim (1944). His piety and simple morality are ridiculed in the West. He falls ill and suffers a nervous breakdown. Upon his return to Cairo, the protagonist looks with horror at his childhood world and in a fit of madness breaks Umm Hashim's holy lamp, a symbol for him (a man of science and reason) of fanaticism and back wardness. The setting for Soheil Idris's novel, The Latin Quarter is the Paris of early 1950s where a group of Arab students seek higher education and socialize with the beatiful girls of the bohemian quarter. Following a sad love affair with one of them, the hero return to Beiruty where he rebels against his mother, his friends, and their customs. Eventually the young man returns to Paris, finishes his 
doctorate in literature at the Sorbonne and comes back to Beirut to become a passionate advocate of Arab nationalis (TakieddineAmyuni, 1980: 1-18).

These novels describe simple themes of unhappy encounters with Westernism, of sexual liberalition and freedom. None of them, however, offers a sophisticated analysis of the encounter with the West and upon returning the difficulties of the encounter with tradition. A more complex treatment of such themes is undertaken by the Sudanese novelist Tayeb Salih in his Season of Migration to the North (Salih, 1978). The hero of this novel is the narrotor who begins as a romantic young man, spends seven happy years in London and then returns to his village in the Sudan. There here discovers Mustapha Saeed (who had also spent several years in London) engulfed in what Frantz Fanon had called a "Circle of Hell" (Fanon, 1969:68-74). The narator goes through romance, tragedy, and hatreds to become aware of the insignificance of human differences in comparison to the historical flow of events.

\section{Islam and Postmodernism}

Tayeb Salih's narrator is the prototype of the modern Arab who comes to terms with the modernity, its anxiety and its promise, by forging an identity in the midst of rapid social and political change. God is absent from the narrator's life and so are the transcendental values associated with rituals and festivals. Feelings of the absurd and of radical doubt permeate the novel. On his journey of self discovery, the narrator experiences and overcomes three major crises: upon his return to his village, he discovers an identity based on family, tribe, loving parents, brothers and sisters, and a grandfather who link him to the past. He does not reject this past completely. For him, the village represents stability and constancy in the midset of change, a place of purity because it has not been touched by foreign intruders. In the second, he is able to achieve love (and trust) by resolving what Erikson (1969) calls the crisis of intimidacy. In the third, he is exposed to the germs of 
violence and oppression spread by Saeed, over comes the temptation and rises above all of this to a new feeling of hope. In the end, the author depicts the following affirmation of an evolving identity:

I must be one of those birds that exist only in one region of the world...Over there is like here, neither better nor worse. But I am here from here, just as the date palm standing in the courtyard of our house has grown in our house and not in anyone else's. The the fact they came to our land, I know not why, does that mean that we should poison our present and our future ? Sooner or later they will leave our country jus as many people throughout history have left many countries. The railways, ships, factories, and schools will be ours and we will speak their languange without either a sense of guilt or a sense of gratitude. Once again we shall be as we were ordinary people- and if we are lies we shall be lies of our own making (Salih, 1978: 45-50).

Tayeb Salih's narrator discovers his ordinariness in his search for authenticity and opts for what Gidden (1991:214) call "life politics" which ultimately concern "political issues which flow from processes of self -actualization in post-traditional contex, where globalizing influences intrude deeply into the reflexive project of the self". Life politics, in this case, deal with questions how one should live in a post-traditional order and against a backdrop of existential questions. Gannoushi's journey, on the other hand, is a project of "emancipatory politics" which Gidden defines as a generic outlook concerned above all with liberating individuals and groups from constraints which adversely affect their life chances" (Gidden, 1991:210-211). Emancipatory politics involves two main elements: “ the effort to shed shackles of the past, thereby permitting a transformative attituted toward the future; and the aim of overcoming the illegitimate domination of some individuals or groups by other" (Gidden, 1991:211). Emancipatory politics is 
concerned, abouve all, with themes of justice, equality, and participation, the very same themes that most Muslim reformers are in fact concerned with.

A recent example of scholarship which examines the Muslim phenomenon as an instance of emancipatory politics is Abrahamian's excellent analysis of Khomeinism in the Islamic Republic of Iran. "Khomeinism", he concludes, "despite its religious dimensions, in may ways [it] resembles Latin American populism... a middle calss movement that mobilized the masses with radical sounding rethoric against the external powers and the entrenched power holding cultural and educational institutions than in overthrowing the modes of production and distribution" (Abrahamian, 1993:38).

For Gidden, modernity consists of institutions and modes of behavior which by the middle of the twentieth century has become world historical in their impact. Its key dimensions include industrialism, capitalism, and the institutions of surveillance which are associated withe the rise of the modern nation-state (Gidden, 1990). In the contemporary of Middle East, new states have emerged in the post-World War II periode and gradually have become linked in varying degrees to the rise of industrialism and capitalism in the modern world. These, new states were confronted with a number of crises that posed a variety of issues, among which are the question of legitimacy, decolonization, democracy, development, distribution of resources and integration (Ahmad, 1980;1980a;1981).

The elites which came to power in these state emerged as "modern, educated, managerial elites isolated from the productive process, alienated from their culture sand in the face of continued dependency on external know-how and capital, unable to expand into a productive national bougeoise. This "power elite" in the Muslim countries concentrated its efforts on developing the mechanisms of surveillance by relying on modern bureaucratic methods of control in the context of national-security apparatus. The economicmodels implemented in these countries superimposed upon traditional societies a capitalist economy unaccompannied by 
capitalist culture or capitalist democracy and produced a system at odds with the cultural and political institutions of the people it exploit. This meant that large segments if the population were, for all practical purposes, excluded from the process of economic development. They were, nonetheless, subject to the rigors of the new mechanisms of surveillance, social control, and dehumanization.

How does this system of surveillance filter down to masses and shape everyday life? New practices begin to orient social social relations in the areas of modern education, organized religion, and government expertise; it is all done through elaborate bureaucracies and offical ideologies. These practices produce an effect of structure, meanning and program that is far removed from daily life of the people and has no immediate relevance to their lives. But it displaces village entertainments, small feast, games, religious events, visits to tombs of holly men, and other locally produced forms of imaginative life (Mitchell, 1990).

The most important effect of these official practices is that they tend to shift the locus of control over the production of symbols, so much a part of the daily life in a Muslim society, to a far away place (the national capital). The process of generating such "enframing" mechanisms and symbols is appropriorited by the organs of the modern state such as the television authority, the national radio, and the Ministry of Information among many others. By and large, the large, the new symbols appear to be alien to local people and far removed from the daily concerns and ways of life.

Yet, even though the grid of modern surveillance penetrates deep into every corner of life in the modern Middle East, society as whole is never completely dominated by it. A variety of "miniscule", "popular" procedures serve to undermine the ubiquitos mechanism of control. Women, for instance, wear the modest dress that covers most of the body and the head as a way of subscribing to a new pattern of Islamic behavior and as a form of resistance to dominant Western pattern of dress. Muslim attire becomes an affirmation of an 
identity and a rejection of Western habits. For many young men, wearing a beard become a similar symbol. This is part of what Kepel (1984), in his analysis of modern Egypt, call "popular forms of expression" that have flourished in Egypt in a "welter of forms of expression ranging from what Michael certeau has called 'ways of getting by' to more elaborate forms of communalism like the Sufi brotherhoods" (Kepel, 1984:232).

These popular forms of resistance occur because people do have a limited margin of autonomy in areas which are immune to control by the institutions of legal political life. Mosques in poor urban neighborhoods and various religious organizations and charities often constitute the web of such resistance activities. Sometimes, more elaborate forms of resistance to oppression begin to emerge in the form of religious reform movements. Some of them might include a militant wing that carries out para-military activities and some may simply rely on political agitation and mobilization. In nearly all cases, these formns of resistance involve a similar psychological trajectory: a process of emigration (hijra) from an alienated society followed by rebellion against it.

In Islamic history, the first and the most important migration (hijra) was of course that of the prophet and his followers who escaped oppressive Mecca to Medina. Here, the prophet established the nucleus of the Muslim polity with a constitutional charter and a system of government. For Shukri Mustapha, for example, one of the leaders of Islamic fundamentalism in Egypt, hijra is first and foremost an act of withdrawal (spiritual and psysical) from jahiliya society (the society that does not recognize God). In the heart of Cairo's poor suburbs, he and his followers tried to create, in tiny furnished flats, a genuinely Islamic society of their own, based on their understanding of Islam (Kepel, 1984:89). For others, like the Tunisian Gannoushi, it meant hijra first to the Levant and then to exile in Europe. For the others still, it meant internal exile in the prisons of the various Arab countries. Prisons, in the Middle East, are commonly referred to as the best schools or universities of political 
training. This is where many Muslim activists end up receiving their basic religious education and underego their conversion to new Islam. If they enter prison with nothing but the rudiments of religious ofpolitical education, they will often as accomplished militants and effective activits.

In a attempt to defuse critisim by militant groups, the Egyptian government recently selected a poor neighborhood in which to build new low-income housing, repair sewers, pave roads, and bring in electricity and running water. The benefits of development, so long denied, have thus belatedly found their way to some of the poor. These symbolic gestures by the state are juxtaposed to self-help efforts by Islamic groups who consistently feed the poor, educate their children. Provide them with basic health care, and come to their aid following a recent earthquake. In the process, Islamic groups established parallel structures which provide the kind of assistance that the modern state has given only to the privileged.

\section{CONCLUSION}

One may conclude that there is indeed a alternate Islamic religious and moral experience which differs makedly from the official experience generated by the various governments that came into being in the post-World War II period. In its broad outlines, it represents a fundamental act of rebellion against alienating experiences, that result from the inclusion of the Arab world into a global system dominated by modernism and its institutions. As such, this rebllion removes large masses of people from the market of modern consumption and poses serious challenges to the modern apparatus of control and surveilance.

At its core, the new Islamic experience involves a redefination of identity in a world which has become homogenized by the globalizing process of modernism. It is, at the same time, an assertion of the ned to reject diversity in the cultural and social spheres of life and call for more active participation in the political sphere. The 
Islamic experience is therefore a call for an emancipatory politics which means justice where there is none, a more egalitarian distribution of wealth and a more democratic system of decision making.

The teoritical work remains to be done; nowhere in the contemporary Islamic literature does one find, for example, a formulation similar yo John Rawls's theory of justice or even an awereness of the rich political and philosophical critique now being formulated in the West by major thinkers whose work represents a reformulation of the core of modernism. At the same time, major efforts need to be made toredefine social relations in a way that meets the basic criteria of democracy in an Islamic society: What are the basic guarantees of human rights and civil liberties? What guarantess are there for minorities ? What is the role of women in Muslim society?

The status of women appears to be much on the minds of the leading the teoriticians of the new Islamic movements. The Sudanese scholar-political activist Hasan Turabi (1992), for example suggests that the status of women must be redefined in a way that guarantees full equality form women in all areas of public life. He makes a distinction between "historical Islam" where certain erroneous practices have intruded into the behavior of Muslim and "real Islam" which does not sanction the oppression of women. It remains to be seen what new formulations are made and how they are implemented. Given the fact that the majority of the new activists are highly educated men and women, it is unlikely that the prevailing oppresive conditions which have characterized the status of women in Muslim society will contineu to exist. Change is much more likely to occur among the new Muslim activists and not in the more traditional societies in Arab world (such as the more oppresive countries of the Gulf, Saudi Arabia, Kuwait, and others).

Wether the new Islamic movements eventually achieve political and cultural hegemony in the Arab world cannot be predicated. However, the Arab world will undoubtedly be altered as 
a result of their emergence. So one should not be too quick to dismiss them as emphemeral ideological eruptions which are likely to be superseded or coopted by the moreawesome power of the modern state.

\section{REFERENCES}

Abraham, E. 1993. Khomeinism.The University of California Press, Berkeley.

Ahmad, E. 1980. From Potato Sack to Potato Mash: The Contemporary Crisis of the Third World. Arab Studiest Quarterly 2: 223-234 . 1980a. Postcolonial Systems of Power. Arab studiest Quartery 2:350-365.

. 1981. The Neo Facist State: Notes on the Pathology of Power in the Third World. Arab Studies Quarterly 3:170-180

Erikson, E. 1969. Childhood and Society. Norton, New York.

Fanon, F. 1969. The Wretched of The Earth. Penguin, New York

Gannoushi, R. 1991. Interview. Qiraat Siyasiyyah (in Arabic) 1:5-40. 1991. Interview with Rashed Gannoushi. Qiraat Siyasiyyah (in Arabic) 2:157-184.

Gidden, A. 1991. Modernity And Self-Identity. Stanford University Press, Stanford. . 1990 The Consequences of Modernity. Polity, Cambridge.

Huntington, S. 1993. The Clash of Civilization. Foreign Affairs 72:22-49 Joseph, R. 1981. Semiotics of the Islamic Mosque. Arab Studies Quarterly. 3:275-184.

Kepel, G. 1984. Muslim Extremism In Egypt. University of California Press, Berkeley.

Lewis, B. 1990. The Root Of Muslim Rage. The Atlantic Montly. September 47-64.

Mannheim, K. 1952. Essays On The Sociology Of Knowledge. Routledge And Kegan Paul, London.

Marty, M,. A'la, A. 1980. Fundamentalisms Of Islam. Islamic Publications, Lahore. 
Mitchell, T. 1990. Everyday Metaphors Of Power. The theory and Society 19: 545-577.

Rosenau, P. 1992. Postmodernism And The Social Sciences. Princenton University Press, Princenton.

Said, E. 1993. The Pony Islamic Threat. New York Time Magazine. November 62-65.

Salih, T. 1978. Season Of Migration To The North. Heinemann, London. Takieddine-Amyuni, M. 1980. Tayeb Salih's Season Of Migration To The North. Arab Studies Quarterly. 2:1-18

Turabi, H. 1992. Interview With Dr. Hassan Turabi. Qira'at Siyasiyyah (in Arabic) 3:5-32. 